\title{
砂の形成に関する小・中・大学生の理解と 風化の学習における問題点
}

廣 木 義 久*
山 崎 聡**
平 田豊 誠***

【要約】

砂の形成に関する小・中・大学生の理解を調查し，小・中学校における岩石の風化作用に関する 学習の問題点を議論した。小学 5 学年の単元「流れる水のはたらき」の学習前の児童においては, 砂の形成メカニズムに関する考えは極めて多様であるが,「流れる水のはたらき」の学習後は, 侵食 モデル（砂は川で石や岩が水流によって削れてできる）で説明する児童と, 衝突モデル（砂は川で 砂同士がぶつかり合って砕けてできる）で説明する児童が増加する（それぞれ $29.9 \% ， 25.6 \%$ )。そ して, 中学校に㧍ける単元「活きている地球」の学習後は, 侵食モデルが $52.5 \%$ と増加する一方, 風化モデルで説明する生徒の割合は $8.8 \%$ にとどまった。これらの結果から，侵食モデルと衝突モ デルは小学 5 学年の「流れる水のはたらき」の学習で獲得され, 侵食モデルは中学 1 年の風化・侵 食作用の学習後に強化されていることがわかる。岩石の風化作用による砂の形成を理解させるため の方策としては, 中学校における岩石の風化作用の授業に土の学習を取り入れることが有効である と考えられる。

\section{I.はじめに}

砂および砂岩は, 小・中学校の地学分野における学習

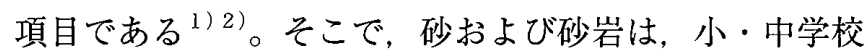
の教師を目指す教員盖成課程の学生にとっても必須の学 習内容である。

筆者らは, 教員養成課程の学生が, 砂がどのようにし てできると考えているのかを調査した。砂はどこでどの ようにしてできると思いますか」と質問し，自由記述で 回答してもらった（回答者数は 49 )。その結果, $32.7 \%$ の学生が「砂は川で水流によって削れて（侵食されて） できる」(以下，侵食モデルと呼ぶ）と回答し， $36.7 \%$ の 学生が「砂は川で碟同士がぶつかり合って砕けてでき る」(以下, 衝突モデルと呼ぶ) と回答した（表 1 ; 図 1 )。 「山などで風化によってできる」（以下，風化モデルと呼

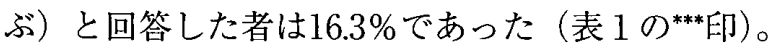

学問的には, 砂そのものの形成に焦点を当てた研究は

\footnotetext{
*大阪教育大学教育学部

**大阪教育大学附属池田小学校 (現所属: 池田市立池田小学校) ***大阪教育大学附属池田中学校
}

多くはないが, 河川堆積物の下流方向への粒径変化に関 する研究は多〈なされている314)5)。その中で, 河川堆 積物の下流方向への粒径変化（減少傾向）における礫の

(1) 侵食モデル

(A) 石が削られて

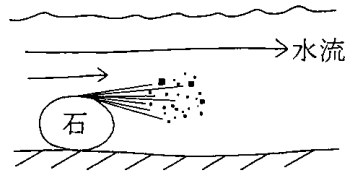

(B) 岩が削られて

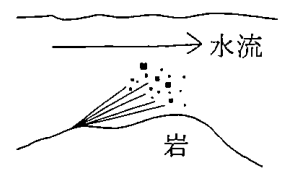

(2) 衝突モデル

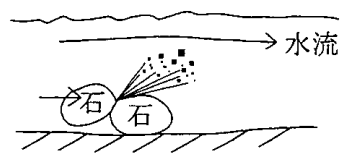

図1 砂の形成メカニズムに関する2つのモデル 
廣木・山崎・平田 : 砂の形成に関する小・中・大学生の理解と風化の学習における問題点

表 1 「砂はどこでどのようにしてできるのか」に対する大学生の回答結果

(回答者49名, 自由記述, 複数回答, カッコ内は回答者率)

\begin{tabular}{|c|c|c|c|c|c|}
\hline \multirow[t]{2}{*}{ 砂の形成場所 } & \multirow[t]{2}{*}{ 回答者数 } & \multicolumn{4}{|c|}{ 砂の形成メカニズム } \\
\hline & & 削られて・侵食されて & 砕けて & 風化して & その他 \\
\hline 川 & $31(63.3 \%)$ & $16(32.7 \%)^{*}$ & $18(36.7 \%)^{* *}$ & $0(0.0 \%)$ & $1(2.0 \%)$ \\
\hline 海 & $13(26.5)$ & $5(10.2)$ & $8(16.3)$ & $0(0.0)$ & $1(2.0)$ \\
\hline 山 & $7(14.3)$ & $6(12.2)$ & $0(0.0)$ & $3(6.1)^{* * *}$ & $0(0.0)$ \\
\hline 岩や石のある所 & $6(12.2)$ & $5(10.2)$ & $0(0.0)$ & $3(6.1)^{* * *}$ & $0(0.0)$ \\
\hline 至る所 & $2(4.1)$ & $2(4.1)$ & $0(0.0)$ & $1(2.0)^{* * *}$ & $0(0.0)$ \\
\hline 水中 & $2(4.1)$ & $1(2.0)$ & $1(2.0)$ & $0(0.0)$ & $0(0.0)$ \\
\hline 地面 ·地上 & $1(2.0)$ & $1(2.0)$ & $0(0.0)$ & $1(2.0)^{* * *}$ & $0(0.0)$ \\
\hline
\end{tabular}

:侵食モデル, ${ }^{* *}$ :衝突モデル, ${ }^{* * *}$ :風化モデル

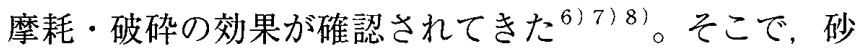
の形成に関して多くの学生が回答した侵食モデルや衝突 モデルは，学問的にも間違いとは言えない。しかし，こ こで筆者らが問題としたいのは，砂の形成における岩石 の風化作用の重要性があまり理解されていないという点 である。砂の形成に関して，岩石の風化作用が重要な役 割を果たしていることは明らかである ${ }^{9) 10\} 。 ~}$

学生の多くが, 砂は川で碟が削れたり砕けたりしてで きる，と考えるようになったことには，小・中学校での 学習が関わっていると考えられる。前述の大学生への調 查において，「回答した考えは，いつ，どこで知りました か」と質問したところ，ほとんどの学生は「小学生ある いは中学生の時に, 学校の授業で」と回答した。

本論文では，学習者が小・中学校での学習を通して， 砂は川で喽が削れたり砕けたりしてできる，と考えるよ うになる過程を明らかにする。そのためにまず，小・ 中学校学習指導要領の学習内容, および, 小・中学校理 科の教科書における砂の形成に関わる記述内容を分析す る。次に，小・中学校の各学習段階にある児童・生徒を 対象に質問紙調查を行い, 砂の形成に関する理解の変遷 を明らかにする。その上で，小・中学校における岩石の 風化作用の学習における問題点について議論するととも に，中学生が岩石の風化作用をよりよく理解するための 方策を提案する。

ここで，本論文で使用する用語の定義について触れて おく。本論文で使用する碟, 砂, 泥, 粘土は地質学にお ける定義を用い, それぞれの定義で示される粒径をもっ た粒子および粒子の集合体を指す。化学的風化作用によ り形成される粘土を指す場合には粘土鉱物という用語を 使用する。また，土㙵学における土は岩石風化物（砂， 砂, 泥 (シルト・粘土)）と動植物の腐朽分解物との混 合物を指すが11)，本論文においては，土は未固結状態の 岩石風化物（土㙵への移行素材）を指すこととする。ま た, 土砂は砂質成分の多い岩石風化物を指すこととする。

また，風化作用の定義については，広義には風・水・
水による岩石の削磨・削剥を含めることがあるが ${ }^{22)}$ ， こ こでは,「岩石が地表で, その位置を変えることなく（insitu，，地表からの影響により変化・変質すること」の 定義 ${ }^{13)}$ を用いることとする。そこで, 上記の侵食モデ ルには広義の風化作用による砂の形成も含まれることに なるが,ここでは侵食モデルとして一括して扱うことと する。

\section{II. 学習指導要領における砂の形成に関する学習内容}

ここでは，小・中学校における砂の形成に関する学習 内容に焦点をあてる。表 2 に学校学習指導要領の, 表 $3 に 中$ 学校学習指導要領の砂の形成に関連する学習内容 を示す。それぞれ，学習内容の変遷がわかるように，昭 和 33 年, 昭和 43 年, 昭和 52 年, 平成元年, 平成 10 年発行 の学習指導要領について示した。小学校における砂の形 成に関連する単元としては「流れる水のはたらき」およ び「土」について, 中学校における砂の形成に関連する 学習内容としては「風化作用」の内容について抜粋した。

\section{1. 小学校}

流れる水のはたらきに関する学習は昭和 33 年〜平成元 年の学習指導要領では第4学年の学習内容となっており, 平成 10 年の学習指導要領では第 5 学年の学習内容となっ ている。流れる水のはたらきに関する学習では, 改定年 を問わず，（1）流れる水は土地を削ること，(2) 流れる 水は石や土（砂や粘土）を流すこと，が学習内容に含ま れている。

また, 土に関する学習は, 平成元年の学習指導要領ま では第 2 学年もしくは第 3 学年の学習内容に含まれてい たが, 平成10年の改定によりその記述がなくなった。昭 和33年改定版には, その学習内容に「土は岩石から変 わったものであること」が含まれている。いわゆる岩石 の風化作用に関わる内容である。昭和 43 年改定版では, 「土には，砂の多いものや粘土の多いものがあること」, 


\section{表2 小学校学習指導要領における砂の形成に関する学習内容}

（下線は筆者による）

\begin{tabular}{|c|c|c|}
\hline 発行年 & 流れる水のはたらきの学習に関連して & 土の学習に関連して \\
\hline 昭和33年 & 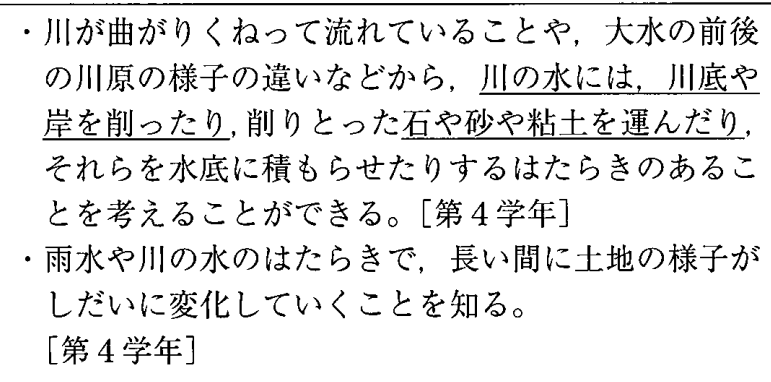 & $\begin{array}{l}\text { ・粘土・砂・黒土などの粒・色・手ざわり, また水の } \\
\text { しみこむ様子や粘り気などを観察して, これらの性 } \\
\text { 質に違いがあることに気づく。 } \\
\text { [第3学年 }] \\
\text { ・がけや切り通しなどで土や岩石を観察したり, 柔ら } \\
\text { かい岩石を哗いたりして, 土は岩石から変わったも } \\
\text { のであることを知る。 } \\
\text { [第3学年 }]\end{array}$ \\
\hline 昭和 43 年 & $\begin{array}{l}\text { •川原の石や砂などは, おもに川上から流されてきた } \\
\text { ものであること。[第 } 4 \text { 学年 }] \\
\text { •流水のはたらきで川岸や海べなどの様子が変わるこ } \\
\text { と。[第 } 4 \text { 学年 }]\end{array}$ & $\begin{array}{l}\text { ·土は粒の大きさによって, 水のなかで沈む速さに違 } \\
\text { いがあること。[第 } 3 \text { 学年 }] \\
\cdot \text { 土には，砂の多いものや粘土の多いものがあるこ } \\
\text { と。[第 } 3 \text { 学年 }]\end{array}$ \\
\hline 昭和52年 & $\begin{array}{l}\text { ・雨水及び川の水の流れは，土地を削ったり，石，土 } \\
\text { などを流したり積もらせたりすること。[第 } 4 \text { 学年 }]\end{array}$ & $\begin{array}{l}\text { ·砂や土と水とを使った活動を工夫させながら, 砂や } \\
\text { 土の手触り, 固まり方, 水の渗み込み方, 水の中に } \\
\text { 入れたときの沈む様子などに違いがあることに気付 } \\
\text { かせる。[第 } 2 \text { 学年 }]\end{array}$ \\
\hline 平成元年 & $\begin{array}{l}\text { ・流れる水には，土地を削ったり，石や土などを流し } \\
\text { たり積もらせたりする働きがあること。[第 } 4 \text { 学年 }]\end{array}$ & $\begin{array}{l}\text { ·土は, 場所によって乎触りや水の渗み込み方に違い } \\
\text { があること。 [第 } 3 \text { 学年 }] \\
\text { ・土は, 小石, 砂, 粘土などからできていて, その混 } \\
\text { じり方は場所によって違いがあること。 [第 } 3 \text { 学年 }]\end{array}$ \\
\hline 平成10年 & $\begin{array}{l}\text { ·流れる水には, 土地を削ったり，石や土などを流し } \\
\text { たり積もらせたりする働きがあること。[第 } 5 \text { 学年 }] \\
\text { ·雨の降り方によって, 流れる水の速さや水の量が変 } \\
\text { わり, 増水により土地の様子が大きく変化する場合 } \\
\text { があること。[第 } 5 \text { 学年 }]\end{array}$ & （記述なし） \\
\hline
\end{tabular}

\section{表 3 中学校学習指導要領における風化作用および侵食作用に関する学習内容} (下線は筆者による)

\begin{tabular}{|c|c|c|}
\hline 発行年 & 風化作用に関する学習内容 & 侵食作用に関する学習内容 \\
\hline 昭和33年 & $\begin{array}{l}\text { ·岩石は, 風, 水, 温度の変化拉よび生物などによる } \\
\text { 機械的な作用で風化することを理解する。 } \\
\text { ·岩石は, 空気や水の化学的な作用によって風化する } \\
\text { ことを知る。 } \\
\text { ·土は, 岩石が風化してできたものであること, その } \\
\text { 成分や粒度などによって性質が違うことおよびその } \\
\text { 違いが植物の生育に影響することを理解する。 }\end{array}$ & $\begin{array}{l}\text { ・流水は, 浸食・運搬・たい積の作用で地形を変える } \\
\text { ことを理解する。 } \\
\text { ・海水の浸食・運搬・たい積の作用と, 海食がい, 海 } \\
\text { 食台, 砂州などのでき方を理解する。 } \\
\text { ・地形は, 浸食によって, 長い間に幼年期・壮年期・ } \\
\text { 老年期の順に変わっていくことを理解する。 }\end{array}$ \\
\hline 昭和 44 年 & $\begin{array}{l}\text { ・地表の岩石は, 温度の変化, 流水などのはたらきに } \\
\text { よってこわされること。 }\end{array}$ & $\begin{array}{l}\text { ・流水のはたらきは, 流速や流量に関係があり, これ } \\
\text { によっても地形が変化すること。 }\end{array}$ \\
\hline 昭和52年 & （記述なし） & （記述なし） \\
\hline 平成元年 & $\begin{array}{l}\text { ・いろいろな地形の観察などを通して, 大地が変動し } \\
\text { ていることに気付くとともに, それを地球内部の㗢 } \\
\text { きと関連付けてとらえること。 }\end{array}$ & $\begin{array}{l}\text { ・いろいろな地形の観察などを通して, 大地が変動し } \\
\text { ていることに気付くとともに, それを地球内部の㗢 } \\
\text { きと関連付けてとらえること。 }\end{array}$ \\
\hline 平成10年 & （記述なし） & （記述なし） \\
\hline
\end{tabular}


平成元年改定版では，「土は，小石，砂，粘土などから できていること」という内容が含まれており，土は砂や 粘土からなっていることを学習することになっていた。

先述の大学生に関する調査は平成 19 年度の大学 1,2 回生を対象に実施した。彼らが小学 $3 ， 4$ 年生の時は平 成 7 〜年である。そして，その時に使用されていた学 習指導要領は平成元年改定の学習指導要領である。第 3 学年で, 砂は土の中に含まれていることを学習すること になっているが，ここでは，土の形成が扱われていない ため，砂の形成は扱われていないことになる。第 4 学年 では，流れる水は土地を削る働きがあることを学習して いる。

\section{2. 中学校}

中学校学習指導要領の記述は最近のものほどより抽象 的になっているため, 具体的な学習内容の時代変遷は学 習指導要領からは読みとれない（表 3 )。表 3 より，昭 和33年の学習指導要領には, 「土は，岩石が風化してでき たものであること」，「流水は，・・・地形を変えること」 が学習内容として記述されている。

先の調査対象とした大学生が中学生の時は平成12１5 年である。平成10年改定の中学校学習指導要領の施行が
平成12年度からであるので, 彼らの中学生時代に使用さ れていた学習指導要領は平成10年改定の学習指導要領で ある。平成10年改定の学習指導要領では, 学習内容とし て，風化作用，侵食作用に関する具体的な記述はない。 しかしながら, 後述するように, 当時使用されていた教 科書では風化作用, 侵食作用ともに記述があり, 当時の 中学生はそれらについて学習している。

\section{III. 教科書における砂の形成に関する記述}

学習指導要領によれば, 今も苦も, 小学校では砂の形 成に直接関係する学習はされていない。一方, 中学校で は, 昭和33年の学習指導要領に風化作用による土の形成 についての記述がある。その後の学習指導要領には具体 的な記述はないものの, 教科書では昭和 30 年以降, 常に 風化作用に関する記述は認められる。そこで,ここでは, 昭和30年以降発行の中学校理科の教科書における風化作 用および侵食作用の記述内容を分析する。表4および表 5 に, 中学校理科教科書における風化作用および侵食作 用に関する記述を，教科書の検定年・発行年ごとに示し た。

表 4 中学校理科教科書における風化作用に関する記述

(カッコ内の1〜7の数字は本文中の風化作用の記述の分類番号を示し，ゴシックは砂の形成に関する記述であることを示す）

\begin{tabular}{|c|c|c|c|c|c|c|}
\hline 検定年 & 出版年 & 東京書籍 & 教育出版 & 学校図書 & 大日本図書 & 啓林館 \\
\hline $\begin{array}{l}\text { 昭29-31 } \\
(1954-1956)\end{array}$ & 昭30-34 & $\begin{array}{l}\text { 岩石がしだいにく } \\
\text { ずされ分解してい } \\
\text { くこと }[1,4]\end{array}$ & & $\begin{array}{l}\text { 岩石が細かくくだ } \\
\text { けて土になること } \\
{[3,5]}\end{array}$ & $\begin{array}{l}\text { 岩石の表面がくだ } \\
\text { かれてぼろぼろに } \\
\text { なること } \quad[3]\end{array}$ & $\begin{array}{l}\text { 岩石がこわされた } \\
\text { り変化したりする } \\
\text { こと }[4,7]\end{array}$ \\
\hline $\begin{array}{l}\text { 昭36 } \\
(1961)\end{array}$ & 昭37-40 & $\begin{array}{l}\text { 岩石が土に変わっ } \\
\text { ていくこと [5] }\end{array}$ & $\begin{array}{l}\text { 岩石がこわれて土 } \\
\text { になっていくこと } \\
{[4,5]}\end{array}$ & $\begin{array}{l}\text { 岩石が細かくくだ } \\
\text { けて土になること } \\
{[5]}\end{array}$ & $\begin{array}{l}\text { 岩石がしだいにこ } \\
\text { わされていくこと } \\
{[4]}\end{array}$ & $\begin{array}{l}\text { 岩石がこわされて } \\
\text { 細かくなったり, } \\
\text { 性質のちがったも } \\
\text { のに変化すること } \\
{[4,7]}\end{array}$ \\
\hline $\begin{array}{l}\text { 昭46 } \\
(1971)\end{array}$ & 昭46-47 & $\begin{array}{l}\text { 岩石が地表で変化 } \\
\text { すること } \\
{[7]}\end{array}$ & $\begin{array}{l}\text { 岩石が小さくくた } \\
\text { かれたり, とかさ } \\
\text { れたりして, しだ } \\
\text { いにこわされてい } \\
\text { くこと }[3,4]\end{array}$ & $\begin{array}{l}\text { 岩石が土になるこ } \\
\text { と } \quad[5]\end{array}$ & $\begin{array}{l}\text { 岩石のようすを変 } \\
\text { えて粘土などにす } \\
\text { ること }[6]\end{array}$ & $\begin{array}{l}\text { 地表で岩石が変化 } \\
\text { していくこと }[7]\end{array}$ \\
\hline $\begin{array}{l}\text { 昭55 } \\
(1980) \\
\end{array}$ & 昭55-56 & $\begin{array}{l}\text { 岩石が表面からく } \\
\text { ずれること [1] }\end{array}$ & （記述なし） & $\begin{array}{l}\text { 岩石が土になるこ } \\
\text { と [5] }\end{array}$ & （記述なし） & $\begin{array}{l}\text { 地表で岩石が変化 } \\
\text { していくこと }[7]\end{array}$ \\
\hline $\begin{array}{l}\text { 平4 } \\
(1992)\end{array}$ & 平 $4-5$ & $\begin{array}{l}\text { 岩石が表面からく } \\
\text { ずれていくこと } \\
{[1]}\end{array}$ & $\begin{array}{l}\text { 岩石がくずされ, } \\
\text { 砂や粘土などに変 } \\
\text { 化していくこと } \\
{[4,6]}\end{array}$ & $\begin{array}{l}\text { 岩石が細かくくず } \\
\text { れたり, 質が変わっ } \\
\text { たりして, 砂やど } \\
\text { ろになっていくこ } \\
\text { と }[1,6,7]\end{array}$ & $\begin{array}{l}\text { 岩石がくずれて土 } \\
\text { となること } \\
{[1,5]}\end{array}$ & $\begin{array}{l}\text { 地表で岩石が変化 } \\
\text { していくこと }[7]\end{array}$ \\
\hline $\begin{array}{l}\text { 平13 } \\
(2001)\end{array}$ & 平14 & $\begin{array}{l}\text { 岩石がもろくなる } \\
\text { こと [2] }\end{array}$ & $\begin{array}{l}\text { 岩石がくずれてい } \\
\text { くこ [1] }\end{array}$ & （記述なし） & （記述なし） & $\begin{array}{l}\text { 地表で岩石が砂粒 } \\
\text { やねんどに変わっ } \\
\text { ていくこと [6] }\end{array}$ \\
\hline $\begin{array}{l}\text { 平17 } \\
(2005)\end{array}$ & 平18 & $\begin{array}{l}\text { 岩石がもろくなる } \\
\text { こと［2] }\end{array}$ & $\begin{array}{l}\text { 岩石がもろくなり, } \\
\text { 表面からくすれれて } \\
\text { いくこと }[1,2]\end{array}$ & $\begin{array}{l}\text { 岩石の表面がもろ } \\
\text { くること [2] }\end{array}$ & $\begin{array}{l}\text { 岩石が土や砂にな } \\
\text { ること }[5,6]\end{array}$ & $\begin{array}{l}\text { 地表で岩石が砂粒 } \\
\text { やねんどに変わっ } \\
\text { ていくこと }[6]\end{array}$ \\
\hline
\end{tabular}


表5 中学校理科教科書における侵食作用に関する記述

（カッコ内の1 5の数字は本文中の侵食作用の記述の分類番号を示す）

\begin{tabular}{|c|c|c|c|c|c|c|}
\hline 検定年 & 出版年 & 東京書籍 & 教育出版 & 学校図書 & 大日本図書 & 啓林館 \\
\hline $\begin{array}{l}\text { 昭29-31 } \\
(1954-1956)\end{array}$ & 昭30-34 & $\begin{array}{l}\text { (地表を流れる水が } \\
\text { 土や石をお㧧し, } \\
\text { まさつによって岩 } \\
\text { 石がけずれる)[1] }\end{array}$ & & $\begin{array}{l}\text { 川の水が川岸の岩 } \\
\text { をけずること }[1]\end{array}$ & $\begin{array}{l}\text { 水のはたらきに } \\
\text { よって地面がけず } \\
\text { られていくこと } \\
{[1]}\end{array}$ & $\begin{array}{l}\text { 岩石が少しずつけ } \\
\text { ずりとられること } \\
\text { [1] }\end{array}$ \\
\hline $\begin{array}{l}\text { 昭36 } \\
(1961)\end{array}$ & 昭37-40 & $\begin{array}{l}\text { 水が大地をけずる } \\
\text { こと } \\
\text { [1] }\end{array}$ & $\begin{array}{l}\text { 流れが川底の岩石 } \\
\text { をけずりとったり, } \\
\text { 山腹の土を流して } \\
\text { 地表をあらったり } \\
\text { して, 陸地をしだ } \\
\text { いに低くすること } \\
{[1,2,4]}\end{array}$ & $\begin{array}{l}\text { 雨水や川などが岩 } \\
\text { 石をけずること } \\
\text { [1] }\end{array}$ & $\begin{array}{l}\text { 川が岸をけずった } \\
\text { ク, 谷をきざんだ } \\
\text { クすること[1] }\end{array}$ & $\begin{array}{l}\text { 川の水が川底の岩 } \\
\text { 石をけずったり, } \\
\text { とかしたりして, } \\
\text { 川底をえぐること } \\
{[1,3,5]}\end{array}$ \\
\hline $\begin{array}{l}\text { 昭46 } \\
\text { (1971) }\end{array}$ & 昭46-47 & $\begin{array}{l}\text { 地表を流れる水が } \\
\text { 岩石や土砂をけず } \\
\text { ること [1,2] }\end{array}$ & $\begin{array}{l}\text { 岩石がけずりとら } \\
\text { れること [1] }\end{array}$ & $\begin{array}{l}\text { 流水が表面をけず } \\
\text { ととること [1] }\end{array}$ & $\begin{array}{l}\text { 流水などが地表を } \\
\text { けずること [1] }\end{array}$ & $\begin{array}{l}\text { 流水が陸地の表面 } \\
\text { をけずりとったり, } \\
\text { はがしたり, とか } \\
\text { したりすること } \\
{[1,3]}\end{array}$ \\
\hline $\begin{array}{l}\text { 昭55 } \\
(1980)\end{array}$ & 昭55-56 & $\begin{array}{l}\text { 川は大地をけずる } \\
\text { [1] }\end{array}$ & （記述なし） & $\begin{array}{l}\text { 川や海の水が大地 } \\
\text { をけずりとること } \\
\text { [1] }\end{array}$ & （記述なし） & $\begin{array}{l}\text { 雨水や川の水が風 } \\
\text { 化してくずれや } \\
\text { くなった岩石から, } \\
\text { 岩くずや砂・粘土 } \\
\text { などをけずりとっ } \\
\text { たりとかし去った } \\
\text { りすること }[2,3]\end{array}$ \\
\hline $\begin{array}{l}\text { 平 } 4 \\
(1992)\end{array}$ & 平 $4-5$ & $\begin{array}{l}\text { 水が陸地をけずる } \\
\text { こと [1] }\end{array}$ & $\begin{array}{l}\text { 水の流れにより土 } \\
\text { 地がずられるこ } \\
\text { と [1] }\end{array}$ & （説明なし） & $\begin{array}{l}\text { 地表の土や岩石が } \\
\text { 流水によってけず } \\
\text { りとられること } \\
{[1,2]}\end{array}$ & $\begin{array}{l}\text { 雨水や川の水が風 } \\
\text { 化してもろくなっ } \\
\text { た岩石をけずり } \\
\text { とったりとかし } \\
\text { 去ったりすること } \\
{[1,3]}\end{array}$ \\
\hline $\begin{array}{l}\text { 平13 } \\
(2001)\end{array}$ & 平14 & $\begin{array}{l}\text { 岩石が流水のはた } \\
\text { らきなどによって } \\
\text { けずられること } \\
{[1]}\end{array}$ & $\begin{array}{l}\text { 風化によってもろ } \\
\text { くなった岩石が風 } \\
\text { や流水なとによよっ } \\
\text { てけずられていく } \\
\text { こと [1] }\end{array}$ & $\begin{array}{l}\text { 流水が大地をけず } \\
\text { ること [1] }\end{array}$ & （記述なし） & $\begin{array}{l}\text { 雨水や流水が風化 } \\
\text { した岩石をけずり } \\
\text { とったり, とかし } \\
\text { 去ったりすること } \\
{[1,3]}\end{array}$ \\
\hline $\begin{array}{l}\text { 平17 } \\
(2005)\end{array}$ & 平18 & $\begin{array}{l}\text { 岩石が流水のはた } \\
\text { らきなどによって } \\
\text { けずられること } \\
{[1]}\end{array}$ & $\begin{array}{l}\text { 風化によってもろ } \\
\text { くなった岩石が風 } \\
\text { や流水などによっ } \\
\text { てけずられていく } \\
\text { こと }[1]\end{array}$ & $\begin{array}{l}\text { 岩石の表面が流水 } \\
\text { によってけすられ } \\
\text { ること [1] }\end{array}$ & $\begin{array}{l}\text { 風化によってもろ } \\
\text { くなった岩石が風 } \\
\text { や流水などによっ } \\
\text { てけずられること } \\
{[1]}\end{array}$ & $\begin{array}{l}\text { 雨水や流水が風化 } \\
\text { した岩石をけずり } \\
\text { とったり, とかし } \\
\text { 去ったりすること } \\
{[1,3]}\end{array}$ \\
\hline
\end{tabular}

\section{1. 風化作用}

各教科書における風化作用の説明を分類すると次の 7 つになる。

1. 岩石がくずれていくこと。

2．岩石がもろくなること。くだけやすくなること。

3.岩石が砕けていくこと。

4，岩石がこわれたり，分解すること。

5. 岩石が土になること。

6. 岩石が砂や粘土に変化すること。

7. 岩石が地表で変化すること。

これらの記述のうち, 砂の形成に関連した記述は 6 の 記述である。また，5の記述も，土の中に砂が含まれる
ことを考えれば,砂の形成の記述と捉えることができる。 したがって, 5 や 6 の記述をしている教科書においては, 岩石の風化作用による砂の形成（風化モデル）を扱って いると言える。

表 4 をみると, 同じ出版社の教科書でも, 検定年によっ て説明が異なっている。砂の形成の記述（上記の 5 もし くは 6）をしている教科書は昭和 36 年検定の東京書籍, 昭和36年, 平成 4 年検定の教育出版, 昭和 31 年, 36年, 46 年, 55 年検定の学校図書, 昭和 46 年, 平成 4 年, 17 年 検定の大日本図書, 平成13年, 17 年検定の啓林館の教科 書である。 
廣木・山崎・平田 : 砂の形成に関する小・中・大学生の理解と風化の学習における問題点

\section{2. 侵食作用}

次に，各教科書における侵食作用の記述を分類すると

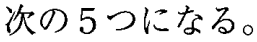

1. 岩石・土地・陸地・地表面が（流水などによって） 削られること。

2.土，土砂，碟・砂・粘土が（流水などによって）削 られること。

3. 岩石が溶かし去られること。

4.土砂を流したりすること。

5.川底がほり下げられること。

これらの記述のうち，ほとんどの教科書が 1 の記述を 採用している（表 5 ）。1の説明にある岩石については, 単に「岩石」としか述べられていない場合の他に,「風化 によってもろくなった岩石」とか「風化した岩石」など と述べられている場合がある。5の記述は川底の砂碟が 流されることによる侵食作用を述べているが，5のよう な説明は表5の中では昭和36年検定の啓林館の教科書に のみ見られる。

本論文の最初に示したように，大学生の多くは,「砂は 石や岩が川で水流によって削れて（侵食されて）できる」 (侵食モデル)，もしくは，「砂は川で礫同士がぶつかり 合って砕けてできる」(衝突モデル) と考えている。

中学校の教科書では砂の形成についての記述が見られ ないものもあるが，記述がある場合には風化モデルに よって説明されており，侵食モデルや衝笑モデルで説明 している教科書は見当たらない。それにも関わらず，多 くの学生は砂の形成を侵食モデルもしくは衝突モデルで 説明する。

中学校の教科書では, 砂は侵食作用によって形成され るとは説明していないが，多くの教科書が，侵食作用を 「岩石が流水によって削られること」と説明している（表 5 )。そこで, 学生はこの記述により, 岩石が流水によっ て削り取られることにより砂が形成されると連想したも のと考えられる。

また，先に示したように，小学校の単元「流れる水の はたらき」では,「流れる水には土地を削ったりする働き があること」を学習する（表 2 )。これも侵食作用の学 習である。そこで，侵食モデルは小学校および中学校の 学習によって獲得された可能性が高い。

一方，衝突モデルについては，砂の形成に関してその ような説明は中学校の教科書には見当たらない。しかし， 小学校の単元「流れる水のはたらき」に関して, 現行の 小学 5 年の教科書を調べると，ほとんどの教科書に川原 の礫の形状に関寸る記述が見られる。そして，流れる水 のはたらきによって啋が運搬されることによって礫の形 が丸くなることを理解させる記述がなされている。例え ば, 平成17年発行の教育出版の教科書では,「川の石は, 上流から下流に運ばれるうちに，ぶつかって角がとれた
りして，しだいに小さく丸くなります」と説明されてい $ろ^{14)}$ 。

これらの教科書では，礫が衝突することにより砂がで きるとは述べられてはいないが，礫が衝突することによ り砕かれて丸くなる，と記述されている。学習者は，こ の記述により，砂が衝突することによって砕かれて砂が 形成されると考えるようになっているものと思われる。 つまり, 砂の形成に関する衝突モデルは小学 5 年生の「流 れる水のはたらき」の学習によって獲得された可能性が 高い。

\section{N. 小.中学生の砂の形成に関する理解}

大学生の砂の形成に関する理解に関して，侵食モデル は小学校および中学校での侵食作用の学習によって獲得 された可能性が高く, 衝突モデルは小学校での磁の円磨 の学習によって獲得された可能性が高いことが予想され た。そこで, ここでは，この仮説を小・中学生への質問 紙調査によって検証する。

\section{1. 調査方法}

現行の学習指導要領では, 砂および砂岩に関する学習 は小学校第5学年・第6学年, および中学校でなされてい る(5)16)。これらの学習が, 巟童・生徒の砂の形成に関す る理解とどのように関わっているのかを検討するため に，砂の形成に関する質問紙調査を行った。調査は大阪 教育大学附属池田小学校の 5 年生 120 名および 6 年生 117 名, 同附属池田中学校の 1 年生 80 名および 2 年生 80 名を 対象に行った。いずれにおいても，「すな（砂）はどこで, どのようにつくられると思うか」と質問し, 自由記述に より回答してもらった。

調査は以下の時期に行った。小学 5 年生は第 5 学年の 単元「流れる水のはたらき」(流水の学習) の学習前に, 小学 6 年生は第 6 学年の単元「大地のつくり」（地層の 学習) の学習前に, 中学 1 年生は理科第 2 分野「活きて いる地球」の学習前に行った。中学 2 年生は中学 1 年の 時に「活きている地球」(風化・侵食の学習) を学習済 みである。したがって, この調査により, 小学校第5学 年の単元「流れる水のはたらき」の学習の前後, 小学校 第 6 学年の単元「大地のつくり」の学習の前後, 中学校 第 1 学年の単元「活きている地球」の学習の前後におけ る児童・生徒の砂の形成に関する理解状況を知ることが できる。そこで, 児童・生徒の砂の形成に関する理解が それぞれの段階における学習によりどのように変化する のかを検討することができる。

\section{2. 結果}

図 2 に，「砂はどこでできるのか（砂の形成場所）」に 


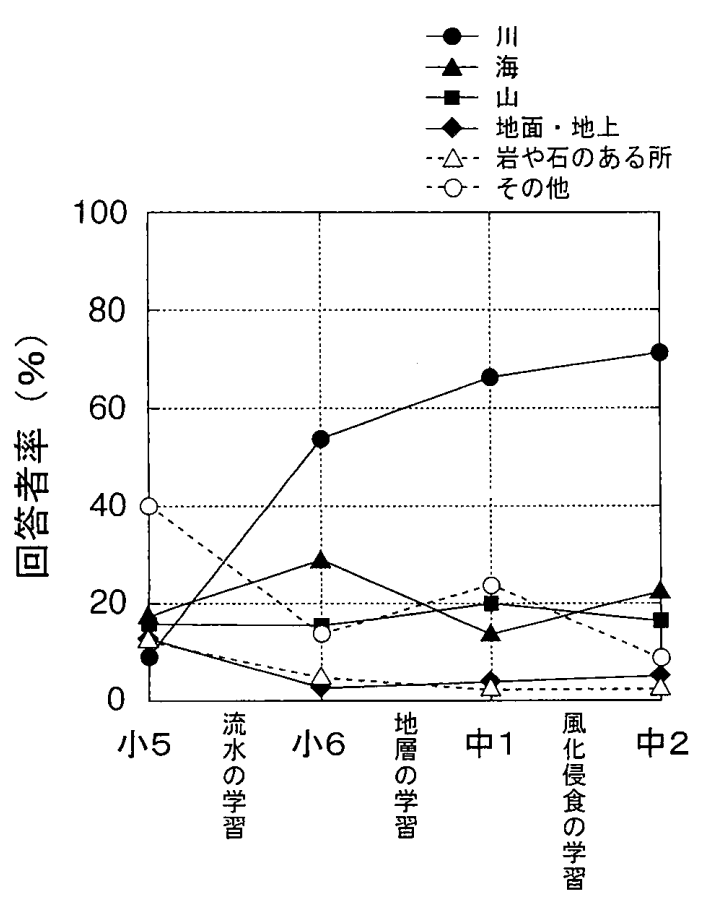

学習段階

図 2 砂の形成場所に関する各学習段階ごとの理解とそ の変化

(小 5 と小 6 の間の「流水の学習」は単元「流れる水の はたらき」の学習を, 小 6 と中 1 の間の「地層の学習」 は単元「大地のつくり」の学習を, 中 1 と中 2 の間の「風 化侵食の学習」は単元「活きている地球」の学習を表す)

関する回答結果を，図3に「砂はどのようにしてできる のか（砂の形成メカニズム）」に関する回答結果をまと めた。横軸に各学習段階を，縦軸に回答者率をとり，各 学習段階において回答がどのように変化するかを示した。

まず，砂の形成場所に関する回答を分析する（図 2)。 砂の形成場所に対する回答を「川」,「海」,「山」,「地面・ 地上」「岩や石のある所」「その他」に分類した。「流れる 水のはたらき」の学習前の小学 5 年生においては, 回答 は多様であり，「その他」の回答者率は $40.0 \%$ ある。「そ の他」に含まれる回答としては, 砂漠, 火山, 宇宙, 工 場, 地球の中, などがある。一方,「川」,「海」,「山」,「地 面・地上」，「岩や石のある所」と回答した者の割合はそ れぞれ9.2\%，17.5\%，15.8\%，12.5\%，12.5\%と，いずれ も 2 割未満である。これが,「流れる水のはたらき」の学 習後の小学 6 年生になると,「川」の回答者率が $53.8 \%$ に 増加する。一方, 「その他」の回答者率は $13.7 \%$ に減少し ている。そして,「川」の回答者率は,「大地のつくり」の 学習後の中学 1 年生でさらに増加し,「活きている地球」 の学習後の中学 2 年生でも増加し, $71.3 \%$ となってい る。「海」,「山」の回答者率は学習段階の進展とともに増 減を示すが, 全体的には横這いである。また，「その他」 は全体的に減少傾向を示している。

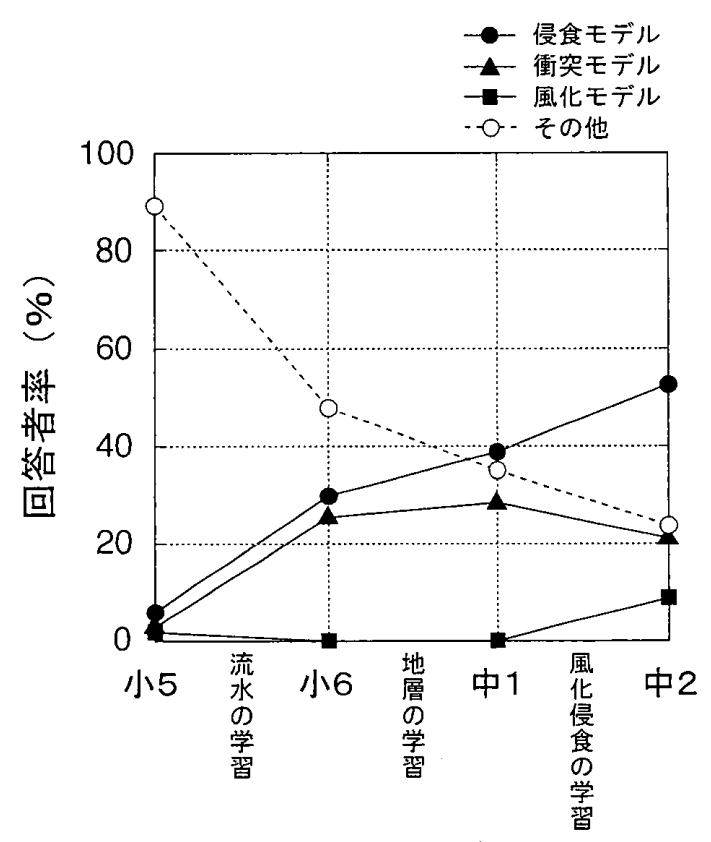

学習段階

図3砂の形成メカニズムに関する各学習段階ごとの理 解とその変化

\section{表6 各学習段階において砂の形成を侵食・衝突・風化} の各モデルで説明している者の割合

(パーセンテージの合計が100を越えるのは複数のモデル で説明している者がいるため)

\begin{tabular}{lcccc}
\hline モデル & $\begin{array}{c}\text { 小学 5 年生 小学6 年生 中学 } 1 \text { 年生 } \\
(\mathrm{n}=120)\end{array}$ & $\begin{array}{c}\text { 中学 } 2 \text { 年生 } \\
(\mathrm{n}=117)\end{array}$ & $\begin{array}{c}\mathrm{n}=80) \\
(\mathrm{n}=80)\end{array}$ \\
\hline 侵食モデル & $7(5.8 \%)$ & $35(29.9 \%)$ & $31(38.8 \%)$ & $42(52.5 \%)$ \\
衝突モデル & $4(3.3)$ & $30(25.6)$ & $23(28.8)$ & $17(21.3)$ \\
風化モデル & $2(1.7)$ & $0(0.0)$ & $0(0.0)$ & $7(8.8)$ \\
その他 & $107(89.2)$ & $56(47.9)$ & $28(35.0)$ & $19(23.8)$ \\
\hline
\end{tabular}

次に, 砂の形成メカニズムに関する回答を分析する(図 3 ; 表 6 )。砂の形成メカニズムを「侵食モデル」,「衝突 モデル」,「風化モデル」,「その他」に分類した。「流れる 水のはたらき」の学習前の小学 5 年生においては「その 他」が89.2\%で，多様な考え方をしているのが分かる。 その考え方の例を挙げると, 海の波で岩が砕けてできる, 砂漠で水が干上がってできる，宇宙の塵が降ってきてで きる，工場で作られる，といったものがある。一方「侵 食モデル」,「衝突モデル」,「風化モデル」はそれぞれ 5.8\%，3.3\%，1.7\%である。これが,「流れる水のはたら き」の学習後の小学 6 年生になると,「その他」が $47.9 \%$ に減少する一方，「侵食モデル」が $29.9 \%$ に,「衝突モデル」 が25.6\%に増加する。これらの割合は，続く「大地のつ くり」の学習後の中学 1 年生ではさほど変化しないが, 「活きている地球」の学習後の中学 2 年生においては,「侵 
廣木・山崎・平田：砂の形成に関する小・中・大学生の理解と風化の学習における問題点

食モデル」が52.5\%に増加し，「衝突モデル」は21.3\%に わずかに減少し、「その他」は $23.8 \%$ に減少する。そして， 「風化モデル」は $8.8 \%$ である。

これらの結果から,「砂は川で石や岩が水流によって削 れて（侵食されて）できる」という侵食モデルと「砂は 川で礫同士がぶつかり合って砕けてできる」という衝突 モデルは, 小学 5 年生の「流れる水のはたらき」の学習 で獲得されることが分かる。そして，中学 1 年生の「活 きている地球」の学習により，一部の生徒は「風化モデ ル」で砂の形成を説明するようになるものの，多くの生 徒は「衝突モデル」を保持し続け,「侵食モデル」はその 「活きている地球」の学習により強化されている。

\section{V. 小・中学生の砂の形成に関する学習の問題点と提案}

砂の形成に関する「侵食モデル」と「衝突モデル」は 小学校に扔ける「流れる水のはたらき」の学習により獲 得され，その考えは中学校における風化作用の学習後も 強く固持され，さらに強化されていることが分かった。 そして, 中学校の風化作用の学習により「風化モデル」 で説明する生徒数が増加するものの，その割合は $8.8 \%$ と極めて低かった。

岩石の風化作用による砂の形成 (風化モデル) を理解 してもらうためにはどのような改善が必要であろうか。

先の教科書の記述の分析で示したように, 中学校の教 科書における風化作用の説明として,「岩石がくずれてい くこと」,「岩石がもろくなること。くだけやすくなるこ と」,「岩石が地表で変化すること」という説明がなされ ている。これらの説明においては, 岩石が風化作用によ り, 砅, 砂, 泥, 粘土の混合物である土に変化すること が述べられていない。岩石の風化作用によって啋, 砂, 泥, 粘土（粘土鉱物）ができることを説明に加える必要 があるものと考えられる。

また，中学校にお打る侵食作用の説明にも改善が必要 である。ほとんどの教科書に扔いて侵食作用は「岩石・ 土地・陸地・地表面が（流水などによって）削られるこ と」と説明されている。この「岩石が削られる」という 表現によって，学習者は, 「砂は硬い岩石が流水で削りと られてできる」と連想するものと考えられる。侵食作用 の説明としては,「岩石や地表を覆う土, 土砂, 磁・砂・ 泥・粘土が流水などによって削られること」という説明 がむしろ望ましいと思われる。

さらに, 岩石の風化作用の教授方法の改善も必要であ ろう。これまでに, 岩石の風化作用に関する教材や授業 の開発がなされてきている(17)18) 19)。これらの新しい教材 や授業方法の導入が風化作用の理解を促すものと思われ る。

そこで，筆者らは，ここに風化作用の学習に土の学習
を含めることを提案したい。土の学習は昭和 33 年の中学 校学習指導要領には記載があった ${ }^{20)}$ 。しかし，昭和44年 の学習指導要領の改定により, 昭和 47 年以降, 土の学習 は教科書から消えた ${ }^{21)}$ 。筆者らは, その土の学習を復活 させることが岩石の風化作用による砂の形成を正しく理 解させる良い方法であると考える。

近年に発行された教科書でも, 風化作用を「岩石が士 や砂になること」と説明しているものもあるが22)，昭和 30年頃の中学校理科の教科書では, 土についてより詳し く説明している。例えば，昭和30年発行の大日本図書の 教科書には, 単元「土と私たちの生活」があり, 土の種 類と性質, 土と植物との関係, 土のでき方, 土地の利用 とその改良の学習が含まれている ${ }^{23)}$ 。土の種類と性質で は，土がいろいろな大きさの粒 (小石・砂・泥・粘土） からなっていることを説明している。そして，土のでき 方では，土の多くは岩石が変化してできたものであるこ と, 岩石の表面がくだかれてぼろぼろになる働きを風化 作用ということ, 土は風化作用によってできること, が 説明されている。

土という用語は日常でもよく使用する用語であり, 生 徒にとっては大変身近な用語である。その身近な土とは いったいどういうものなのか，ということは生徒にとっ ても興味の持ちやすい学習内容であろう。砂（砂粒子） は, もともとは磉や粘土 (粘上鉱物) とともに, 風化作 用によって形成された土の中に含まれているものであ り，その土が侵食され，運搬されるうちに，礫や粘土と 分別されて堆積物としての砂が形成される ${ }^{24) 25)}$ 。

砂は土の中に含まれるということを実感させるため に，昔の教科書では，土と水をビーカーに入れて摚抖さ せたりしている ${ }^{26)}$ 。そのように擋拌したものをフルイに かけて砂を分離させるような実験を行えば，生徒は土の 中に砂が含まれることを理解するであろう。そして，そ のような土は風化作用でできるということを学習すれ ば，砂が風化作用でできることも理解できるであ万う。

\section{V. まとめ}

砂の形成メカニズムのモデルとしての侵食モデルと衝 突モデルは, 小学 5 学年の単元「流れる水のはたらき」 の学習により獲得され, 両モデルは, 中学校における風 化作用の学習後でも保ち続けられ，侵食モデルは侵食作 用の学習によりさらに強化されることが分かった。中学 生が岩石の風化による砂の形成を理解しにくい理由とし て次のようなことが挙げられる。中学校における風化作 用の説明が不十分であり, 岩石の風化作用によって碩, 砂, 泥, 粘土（粘土鉱物）ができることを明確に示して いないため。中学校における侵食作用の説明において 「岩石が削りとられる」という表現により，学習者が「砂 
は硬い岩石が流水でけずりとられてできる」と連想して しまうため。これらの現状を踏まえ，学習者が岩石の風 化作用による砂の形成について正しく理解できるように するための方策として，中学校における風化作用の授業 に土の学習を組み込むことを提案した。現行の教科書で は，砂の形成について必ずしも明確に説明されているわ けではない。今後，砂の形成における風化モデル，侵食 モデル，衝突モデルの重要度についての学術的な研究と 学習におけるそれらのモデルの取り扱い方の検討，中学 校理科に扮ける風化作用の定義についての検討などが必 要である。

\section{謝辞}

大阪教育大学附属池田中学校の中井 昭教諭 (当時), 藤井宏明教諭および同附属池田小学校の矢藤 学講師 （当時）には調査にご協力いただいた。2名の査読者か らは有益なコメントをいただき論文が改善された。以上 の方々に感謝致します。

\section{引用文献}

1) 文部科学省：「小学校学習指導要領解説 理科編」, pp.43-67, 2008, 大日本図書.

2) 文部科学省: ‘中学校学習指導要領解説 理科編」, pp.67-72, 2008, 大日本図書.

3）小玉芳敬・池田 宏・伊勢屋ふじこ：「渡良瀬川に おける粒径別岩種構成比の縦断的変化一沖積碟床河川 における碟の破砕・摩耗効果の重要性一」, 筑波大学 水理実験センター報告, no.13, pp.13-25, 1989.

4 ）谷津栄壽：「平衡河川の縦断面形について (1) (2)

(完)」, 資源科学研究所巣報, 第33号, pp.15-24, 1954, 第34号，pp.14-21，1954，第35号，pp.1-6, 1954.

5）林 慶一・山下浩之：「河川作用の理解の深化で見 る科学的探求の諸局面一探求活動の改善に向けて - 」, 地学教育, 第62巻, 第2号, pp.35-50, 2009.

6）前掲書 3)

7) 前揭畫 4)

8）松川正樹・江澤圭子・西田尚央：「砂の摩耗実験に よる河床础の分布様式の検討：秋川一多摩川水系を例 として」, 地学教育, 第63巻, 第4号, pp.125-133, 2010 .
9 ）堆積学研究会 :「堆積学辞典」, p.146, 1998, 朝倉 書店.

10）松岡憲知 - 由中 博 - 杉田倫明 - 村山祐司 - 手塚 章・恩田裕一：「地球環境学－地球環境を調査・分析・ 診断するための30章一」,p.59，2007，古今書院.

11）秦 明德：「「土」の教材開発」, 理科の教育, 9 月号, pp.46-49, 2010.

12) Jackson, J.A.:Glossary of Geology (4th ed.), p.711, 1997, American Geological Institute.

13）松倉公憲:「地形変化の科学 - 風化と侵食 - 」, p.10, 2008, 朝倉書店.

14）養老孟司ほか：「小学理科 5 上」, p.87, 2005, 教育 出版.

15）前掲書 1)

16）前掲書 2)

17）秦 明德：「化学的風化作用とその教材化一花崗岩 類深層風化殼の場合 -」, 地学教育, 第 43 巻, 第3号, pp.89-100, 1990.

18）岡本 研：「岩石の風化作用から何を学ぶかー岩石 の風化作用と地球環境とのかかわりを考える一」, 北 海道立理科教育センター研究紀要, 第18号, pp.85-94, 2006 .

19）宮崎善郎：「地学分野における身近な自然の教材化 に関する研究一広島地域の招もな地質教材の調査を通 してー」, 広島県立教育センター研究紀要，第35号， pp.69-90, 2008.

20）文部省：「中学校学習指導要領」, p.76, 1958, 大蔵 省印刷局.

21）文部省：「中学校学習指導要領」, 1969, 大蔵省印刷 局.

22）戸田盛和ほか：「新版中学校理科 2 分野上」, p.74, 2006, 大日本四書.

23）坪井忠二ほか：「中学新理科 1 年下」, pp.65-71, 1955 , 大日本図書.

24）Fritz, W.J. and Moor, J.N.著, 原田憲一訳 : 「層序学 と堆積学の基礎」, pp.169-190, 1999, 愛智出版.

25) Pipkin, B.W. and Trent, D.D.著，佐藤 正 ·千木良 雅弘監修：「シリーズ環境と地質 第I巻 地震と火 山と侵食」, pp.170-202, 2003, 古今書院.

26）前揭書23）

（2010年 5 月 2 日受付， 2011 年 3 月 22 日受理） 


\title{
SUMMARY
}

\section{Understandings on the Origin of Sands by Elementary School, Lower Secondary School, and University Students, and Problems on the Lesson of Rock Weathering}

\author{
Faculty of Education, Osaka Kyoiku University \\ Yoshihisa HIROKI \\ Ikeda Elementary School Attached to Osaka Kyoiku University \\ Satoshi YAMASAKI \\ Ikeda Junior High School Attached to Osaka Kyoiku University \\ Toyosei HIRATA
}

The purposes of this research are to exhibit understandings on the origin of sands by elementary school, lower secondary school, and university students, and to discuss problems on the lesson of rock weathering. The fifth-grade students of elementary school have a variety of ideas on the origin of sands. After the lesson of stream water, many students explain the origin of sands by two models: erosion model $(29.9 \%)$ or collision model $(25.6 \%)$, rather than weathering model $(0 \%)$. The percentage of the students who prefer the erosion model increases to $52.5 \%$ after the lesson of rock weathering and erosion in lower secondary school. The percentage of the students who prefer the weathering model is only $8.8 \%$. The results exhibit that the erosion model and the collision model are acquired by the lesson of stream water in elementary school and that the erosion model is strengthened by the lesson of erosion in lower secondary school. Introduction of a lesson of soil may help secondary school students understand the sand-grain formation by rock weathering. 